\title{
Effect of plating temperature on electroless amorphous Ni-P film on Si wafers in an alkaline bath solution
}

\author{
Wang-ping $\mathrm{Wu}^{1,2} \cdot$ Jin-jin Jiang ${ }^{1}$
}

Received: 19 May 2017/ Accepted: 27 June 2017/Published online: 1 July 2017

(c) The Author(s) 2017. This article is an open access publication

\begin{abstract}
Nickel-phosphorus (Ni-P) film was deposited by electroless process on the surface of p-type polycrystalline silicon at the temperature of $60-80{ }^{\circ} \mathrm{C}$ and $\mathrm{pH}$ value of 10.0. The effect of plating temperature on morphology, crystallographic structure, chemical composition and deposition rate of Ni-P film was studied. Microstructure and morphology of surface and cross section of the film were examined by a scanning electron microscopy and optical microscopy. The crystallographic structure and chemical composition of the film were determined by $\mathrm{X}$-ray diffraction and energy dispersive spectroscopy, respectively. The results show that electroless Ni-P films were composed of the amorphous phase. The stable value P-content of the film was maintained at about $12 \mathrm{wt} \%$ with increasing bath temperature. The film surface was dense, and no cracking was found at 60 and $80{ }^{\circ} \mathrm{C}$. However, the film deposited at 70 and $80{ }^{\circ} \mathrm{C}$ had a poor adherence to the substrate with evidence of delamination. The deposition rate of the film was increased with increasing plating temperature. At the same time, the deposition mechanism of the film on silicon substrate in the alkaline bath solution was addressed.
\end{abstract}

Keywords Electroless $\cdot \mathrm{Ni}-\mathrm{P} \cdot$ Temperature

Wang-ping Wu

wwp3.14@163.com

1 Electrochemistry and corrosion Laboratory, School of Mechanical Engineering, Changzhou University, Changzhou 213164, People's Republic of China

2 Jiangsu Key Laboratory of Green Process Equipment, Changzhou University, Jiangsu Changzhou 213164, People's Republic of China

\section{Introduction}

Silicon ( $\mathrm{Si}$ ) wafer is a thin slice of semiconductor material, which could be used for many areas, such as solar cell, integrated circuits, sensors and optical devices, electronic devices and so on. However, the construction of these devices is dependent on quality and purity of silicon wafer (Shacham-Diamand et al. 2015). Metallization of Si wafer is a vital step on device fabrication, which could affect the functional performance of the device (Sudagar et al. 2013; Furukawa and Mehregany 1996). Electroless metal deposition was a more attractive process for metallization in many applications of nanotechnology. Electroless process is a fast, low cost and low energy process without voltage or vacuum condition (Andersson et al. 2008; Zhou et al. 2009; Chen et al. 2001). Uniform and adherent metallic films by electroless could be produced on the surface of $\mathrm{Si}$ wafer. This process could be occurred by the complexed redox reactions of a reductant and an oxidizer in an electrolyte solution.

Nickel-phosphorus (Ni-P) alloy has excellent mechanical, electrical, magnetic and anticorrosive properties, which could be synthesized by electroless process. For electroless process, the deposition conditions, such as bath composition, plating temperature, $\mathrm{pH}$, stirring, plating period, stabilizer and additives, could have a significant influence on the deposition rate, structure an chemical composition and the quality of film (Xie and Zhang 2002; Liu et al. 2006; Singh et al. 2014; Moniruzzaman and Roy 2011; Liu et al. 2015; Rahman and Jayaganthan 2015; Hua et al. 2013). The stability of the electrolyte bath was related with bath chemistry and stabilizer (Osifuye et al. 2014; Bulasara et al. 2011). Therefore, it is necessary to optimize the deposition conditions to obtain a good quality film. Xie and Zhang (Xie and Zhang 2002) studied the effects of bath 
chemistry and $\mathrm{pH}$ value on the structure and amorphous forming region for electroless Ni-P alloys with $9-10$ at \% $\mathrm{P}$-content in the alkaline bath solution at plating temperature of $90{ }^{\circ} \mathrm{C}$ and found that deposition rates had a maximum value with increase in the concentration of $\mathrm{Ni}^{2+}$, $\mathrm{H}_{2} \mathrm{PO}_{2}^{-}$and $\mathrm{pH}$ value, respectively. However, the deposition rates decreased with the increase in the concentration of citrate ions. The $\mathrm{pH}$ value is a significant factor on the complex ions between the $\mathrm{Ni}^{2+}$ ions and complex agent, and the $\mathrm{P}$-content in the deposit depends on the solution $\mathrm{pH}$ value (Lobanova et al. 2011). Liu et al. (Liu et al. 2006) studied the deposition rate of electroless Ni-P films on $\mathrm{Si}$ substrates with prior to sensitization and activation treatment in an acid plating bath increased with increase of the $\mathrm{pH}$ and the plating temperature. Plating temperature is also a significant parameter in determining deposition rate, which is related with the nature of the plated material (Cheong et al. 2007). Until now, few reports studied the effect of plating temperature on electroless Ni-P film on $\mathrm{Si}$ substrates in an alkaline bath solution. In this work, the electroless Ni-P film was plated in an alkaline bath solution on the surface of p-type polycrystalline Si substrates. The effect of plating temperature on the morphology, crystallographic structure, chemical composition and deposition rate of Ni-P film was studied. At the same time, the deposition mechanism of electroless $\mathrm{Ni}-\mathrm{P}$ film on $\mathrm{Si}$ wafers in the alkaline bath solution was addressed.

\section{Experimental}

The p-type polycrystalline $\mathrm{Si}$ wafers were used as the substrates (size: $15 \times 15 \times 0.2 \mathrm{~mm}$ ). One surface of the substrate was etched by reactive ion etching process, which was described in detail in reference (Yoo et al. 2011). Prior to plating, the substrates were cleaned with acetone in an ultrasonic bath for $5 \mathrm{~min}$. A small deposition cell was used for the deposition of the film on the substrates. The bath chemistry and operation conditions are listed in Table 1. No additives and stabilizers were used. The deposition times corresponded at plating temperatures of 60,70 and $80{ }^{\circ} \mathrm{C}$ were set for 40,45 and $40 \mathrm{~min}$, respectively. The volume of bath solutions was $50 \mathrm{~mL}$. All solutions were dissolved in deionized water (Simplicity, Millipore) on a magnetic stirring apparatus with a magnetic stir bar. The $\mathrm{pH}$ of the solution was measured by $\mathrm{pH}$ meter (PHS-3C) under magnetic stirring, and was adjusted to a desired value by adding $5.0 \mathrm{M}$ sodium hydroxide $(\mathrm{NaOH})$ solution at room temperature. A HH-S thermostatic bath was used to control the plating temperature. During plating process, the substrate was put into the electrolyte through a plastic clip without magnetic stirring.

The microstructure and morphology of the top surface and cross section of the film and the substrate were observed by scanning electron microscopy (SEM, JSM6360 and Gemini Sigma 300/VP) operated in the highvacuum mode, equipped with an energy dispersive spectroscopy (EDS) detector. The thickness of the film was observed by optical microscopy (VHX-700FC), fitted with a digital camera. The chemical composition of each sample was tested by EDS detector at five locations to confirm uniformity. The crystallographic structure of the film was determined by X-ray diffraction (XRD, Scintag, USA) equipped with a $\mathrm{Cu}-\mathrm{K} \alpha$ radiation source at a scanning rate of $0.5^{\circ} \mathrm{s}^{-1}$ and scanning from $10^{\circ}$ to $80^{\circ}$ of $2 \theta$.

\section{Results}

\section{Substrate}

Figure 1 shows the XRD pattern and SEM micrographs of surface and fracture surface of pretreated Si substrate. The $\theta-2 \theta$ scan data exhibited strong $2 \theta$ peaks at $28.40^{\circ}, 46.67^{\circ}$, $56.25^{\circ}$ and $76.59^{\circ}$, respectively, corresponding to the (111), (220), (311) and (331) peaks compared with the standard $d$-values taken from JCPDS (43-0144). The XRD pattern revealed that the $\mathrm{Si}$ substrate is a polycrystalline structure (Fig. 1a). After reactive ion etching process, the substrate surface became relatively rough and consisted of many pyramid and pit structures (Fig. 1b). It can be observed from Fig. 1c that the fracture surface was composed of nanometer- to micrometer-sized pores, and the depth of these pores was about $4-5 \mu \mathrm{m}$. The surface morphology of the substrate could affect the microstructure and adherence of electroless Ni-P film.

Table 1 Bath chemistry and deposition conditions

\begin{tabular}{llll}
\hline Bath chemistry $\left(\mathrm{g} \mathrm{L}^{-1}\right)$ & & Deposition conditions & \\
\hline $\mathrm{NiSO}_{4}$ & 25 & Electrolyte $\mathrm{pH}$ & 10.0 \\
$\mathrm{NaH}_{2} \mathrm{PO}_{2}$ & 20 & Deposition temperature $\left({ }^{\circ} \mathrm{C}\right)$ & $60,70,80$ \\
$\mathrm{Na}_{3} \mathrm{C}_{6} \mathrm{H}_{5} \mathrm{O}_{7}$ & 20 & Deposition time $(\mathrm{min})$ & $40-45$ \\
\hline
\end{tabular}



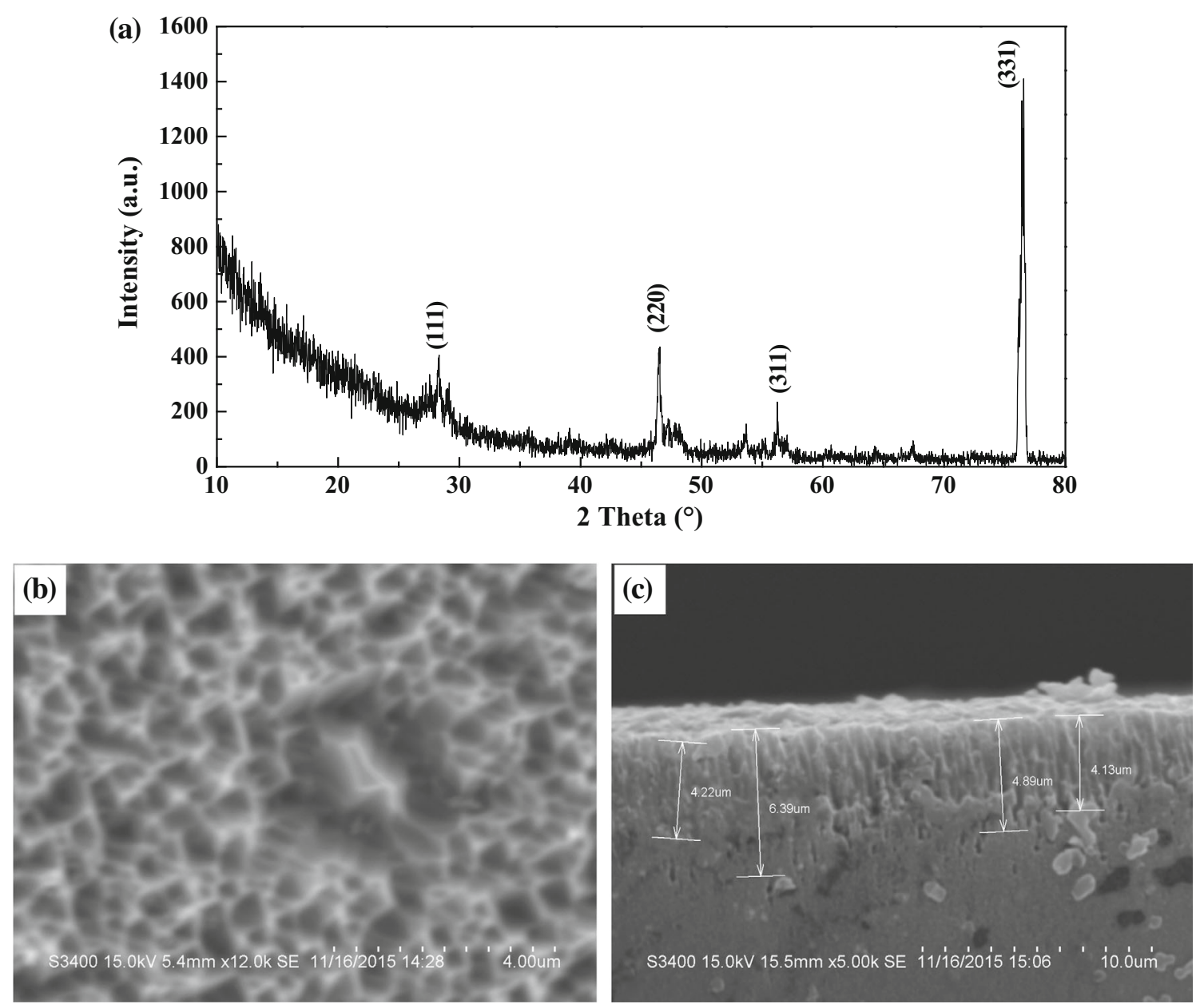

Fig. 1 XRD pattern (a) and SEM micrographs of surface (b) and fracture surface (c) of Si substrate after reactive ion etching process

\section{Characterization of Ni-P film}

Figure 2 shows the SEM micrographs of the film surface deposited at plating temperature of $60{ }^{\circ} \mathrm{C}$. It can be seen from a low-magnification image (Fig. 2a) that the dense surface was composed of some large particles. No microcracks were found on the surface. Many flower patterns and large particles were present in Fig. 2b. Furthermore, the surface of the film was dense, observed by high-magnification SEM micrograph (Fig. 2c, d). A mesoscale colony structure can be observed on the top surface of the deposit. The mesoscale colony and nodules characters were present on the top surface due to the internal stress accumulation during the depositing process (Ashassi-Sorkhabi and Rafizadeh 2004). The film was composed of agglomerated mesoscale colony and nodules, which met and coalesced each other to form a compact layer.

Figure 3 shows the SEM micrographs of the top surface of the film deposited at $70{ }^{\circ} \mathrm{C}$. After mechanical fracture, the Ni-P film exhibited relative softness. The film could be bended to be more than $90^{\circ}$ angle, which can be observed by visible eyes. In Fig. 3a, the film was broken due to the effect of the mechanical fracture. However, it was evidence of delamination for the film on Si substrate. There seems to be a curved film on the surface. The mechanical property of the Ni-P film deposited at $70{ }^{\circ} \mathrm{C}$ would be studied in future work. Furthermore, the surface was dense and smooth, observed by high-magnification SEM micrograph. It seems to be many small particles, but no visible micro-cracks. A mesoscale nodular structure is evidence, with clear intercolony boundaries and surface grooves. These features indicate the film growth is a Volmer-Weber growth mode. The formation of mesoscale nodules resulted from nucleation extending laterally from an existing structural defects (Wu et al. 2015). As shown in Fig. 4, the chemical composition of the Ni-P film presents a uniform distribution. Furthermore, the Ni element was still present on the under layer (Fig. 4a). However, there were no signals of P element on the map scanning image (Fig. 4b).

Some micro-cracks were present on the upper layer of the film around the edge of sample (See Fig. 3b), where release of the hydrogen bubbles caused the microcrackings 

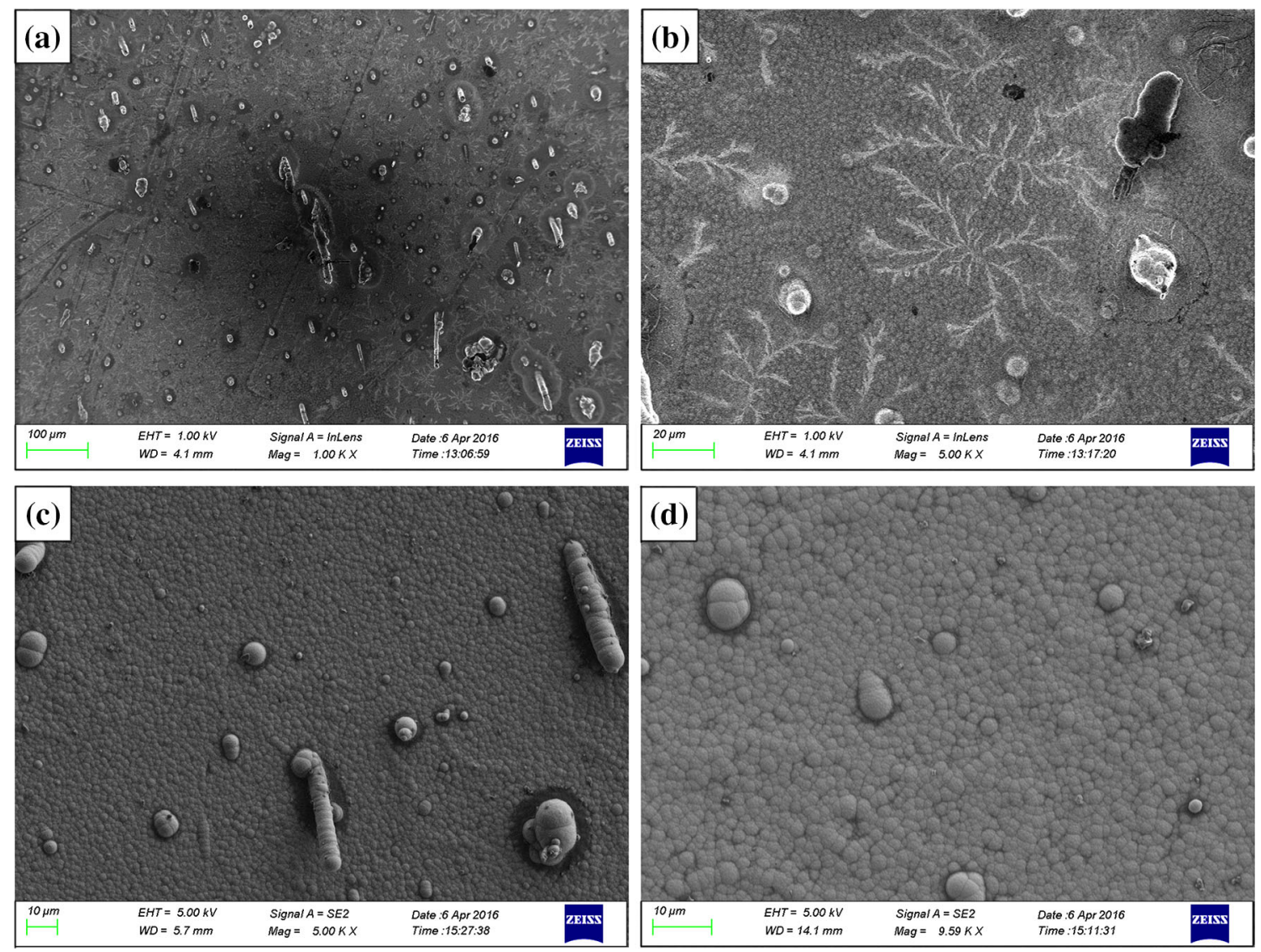

Fig. 2 SEM micrographs of top surface of the film deposited at plating temperature of $60{ }^{\circ} \mathrm{C}$, a magnification $\times 1 \mathrm{~K}$, $\mathbf{b}$ magnification $\times 5 \mathrm{~K}$, c magnification $\times 5 \mathrm{~K}$ and $\mathbf{d}$ magnification $\times 9.59 \mathrm{~K}$

formation. The under layer was composed of nano-sized globular particles. Further, the under layer was composed of a sparse particle distribution. Some regions were not completely deposited by Ni-P particles. It could be influenced by the effect of the competitive of the initial nucleation stage. A mechanism of the electroless Ni-P plating on Si substrates is the nucleation reactions and then film growth. In the initial nucleation stage, the nucleation reactions could occur in the neighborhood of the original $\mathrm{Ni}$ nodules to form an irregular nodular structure (see Fig. 3b). The deposition mechanism of the electroless Ni-P plating on Si substrates will be addressed in "Discussions".

When the plating temperature was increased to $80^{\circ} \mathrm{C}$, the surface of the film became relatively rough after deposition time of $40 \mathrm{~min}$, at the same time the dendritic structure was formed on the surface, and lots of bubbles were released from the electrolyte due to the release of hydrogen. Figure 5 shows the SEM micrographs of the top surface of the film deposited at $80{ }^{\circ} \mathrm{C}$. In Fig. 5a, b, the observed surface was rough. The dendritic structure was present, which was constituted with many small globular particles. The hump and nodules characters on the surface of the deposits were obviously found. No micro-cracking on the surface was observed.

Figure 6 shows the optical images of cross section of the $\mathrm{Ni}-\mathrm{P}$ films on $\mathrm{Si}$ substrates. At $60{ }^{\circ} \mathrm{C}$ temperature, the film was uniform and the thickness was $1.47 \pm 0.12 \mu \mathrm{m}$. It was indicated that the deposition rate was $\sim 0.037 \mu \mathrm{m} \mathrm{min}^{-1}$. In Fig. 6a, the film bonded to the substrate has no evidence of delamination. With increasing bath temperature, the deposition rate remarkably increased. At plating temperature of $70{ }^{\circ} \mathrm{C}$, the film thickness was increased to $3.7 \pm 0.35 \mu \mathrm{m}$ (Fig. 6b). It is depicted that the deposition rate was approximately $0.082 \mu \mathrm{m} \mathrm{min}{ }^{-1}$. The adhesion of the film with the substrate was poor with evidence of delamination. However, the Ni-P film was also found at the untreated surface of Si substrate and the adhesion was also poor. It can be inferred that the Ni-P film could be produced on $\mathrm{Si}$ substrate surface without any pretreatment steps in an alkaline environment. With increasing bath temperature (Fig. 6c), the thickness was about $3.64 \pm 0.14 \mu \mathrm{m}$ and the deposition rate was approximately $0.091 \mu \mathrm{m} \mathrm{min}^{-1}$. The result clearly indicated that the deposition rate increased with increasing temperature up to 

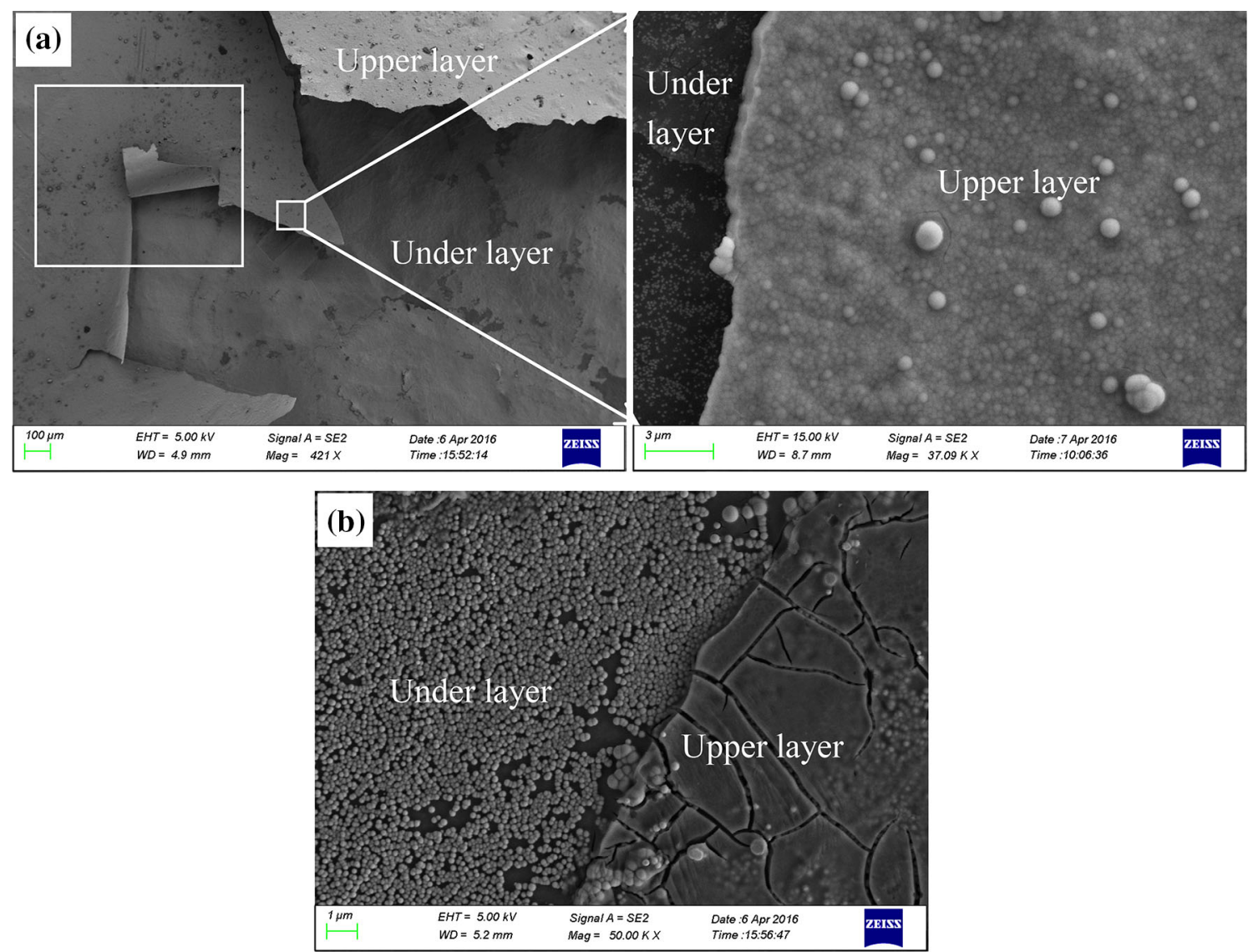

Fig. 3 SEM micrographs of the top surface of the film deposited at $70{ }^{\circ} \mathrm{C}$. a Middle region and $\mathbf{b}$ the edge of sample
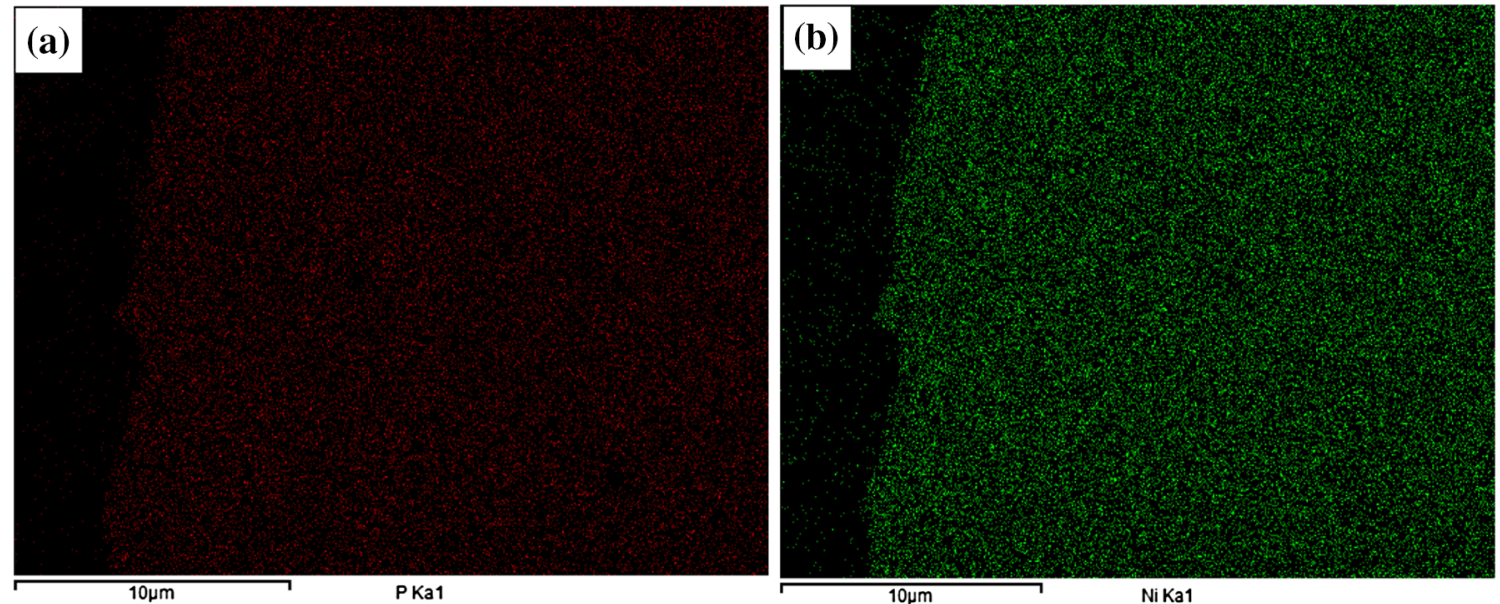

Fig. 4 Map scanning analysis of the EDS of the surface of the film deposited at $70{ }^{\circ} \mathrm{C}$. a Elemental $\mathrm{P}$ and $\mathbf{b}$ elemental $\mathrm{Ni}$

$80{ }^{\circ} \mathrm{C}$, which was consistent with the result of Ref. (Lobanova et al. 2011). This behavior could be due to the increase in the driving force of the reducing agent as a result of the increase in plating temperature (Abdel Hamid 2003; Hung 1985). However, the film had a delamination phenomenon. The adhesion of the electroless deposits to the substrate is primarily mechanical in nature (Wei et al.
2015). In the study, electroless Ni-P films were plated on $\mathrm{Si}$ substrates. The adhesion is dependent upon the surface morphology of the Si surface and the residual stress of the deposits. Mechanical and chemical roughening could provide enough areas and sites into which the Ni-P films became anchored and adhered to the substrates. The Ni-P films deposited at 70 and $80{ }^{\circ} \mathrm{C}$ adhered poor to $\mathrm{Si}$

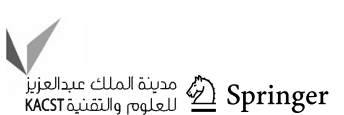



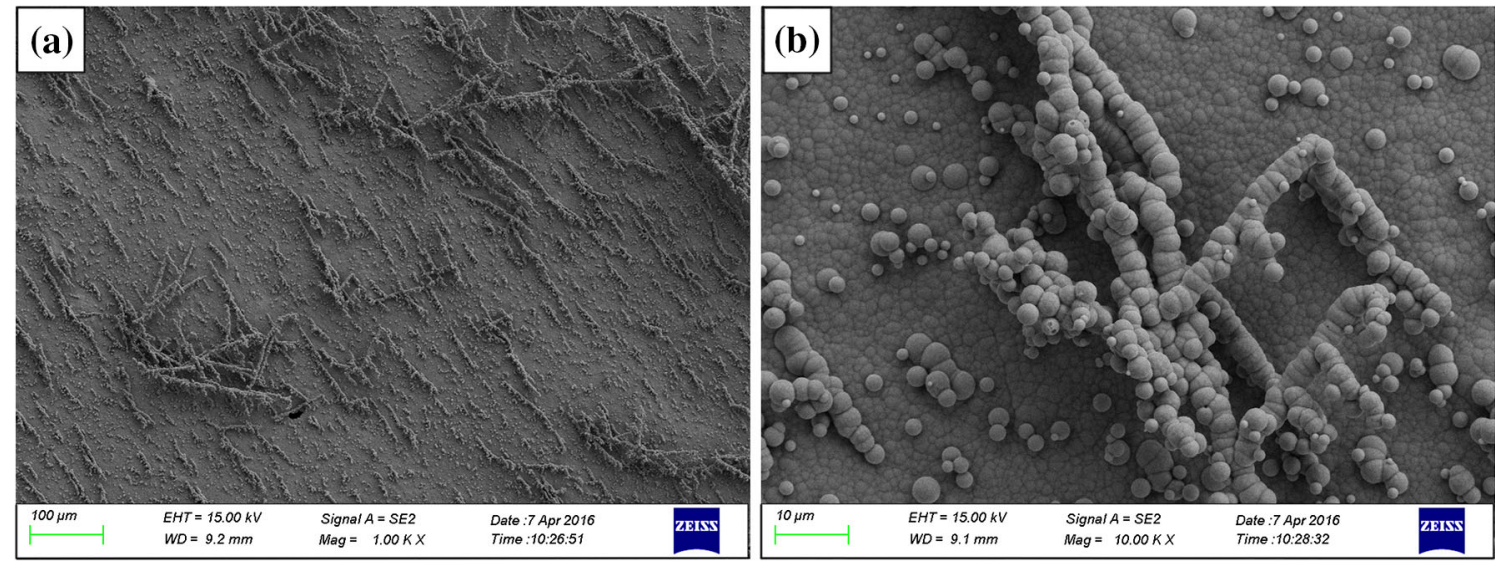

Fig. 5 SEM micrographs of the top surface of the film deposited at bath temperature of $80{ }^{\circ} \mathrm{C}$. a Magnification $\times 1 \mathrm{~K}$ and $\mathbf{b}$ magnification $\times 10 \mathrm{~K}$
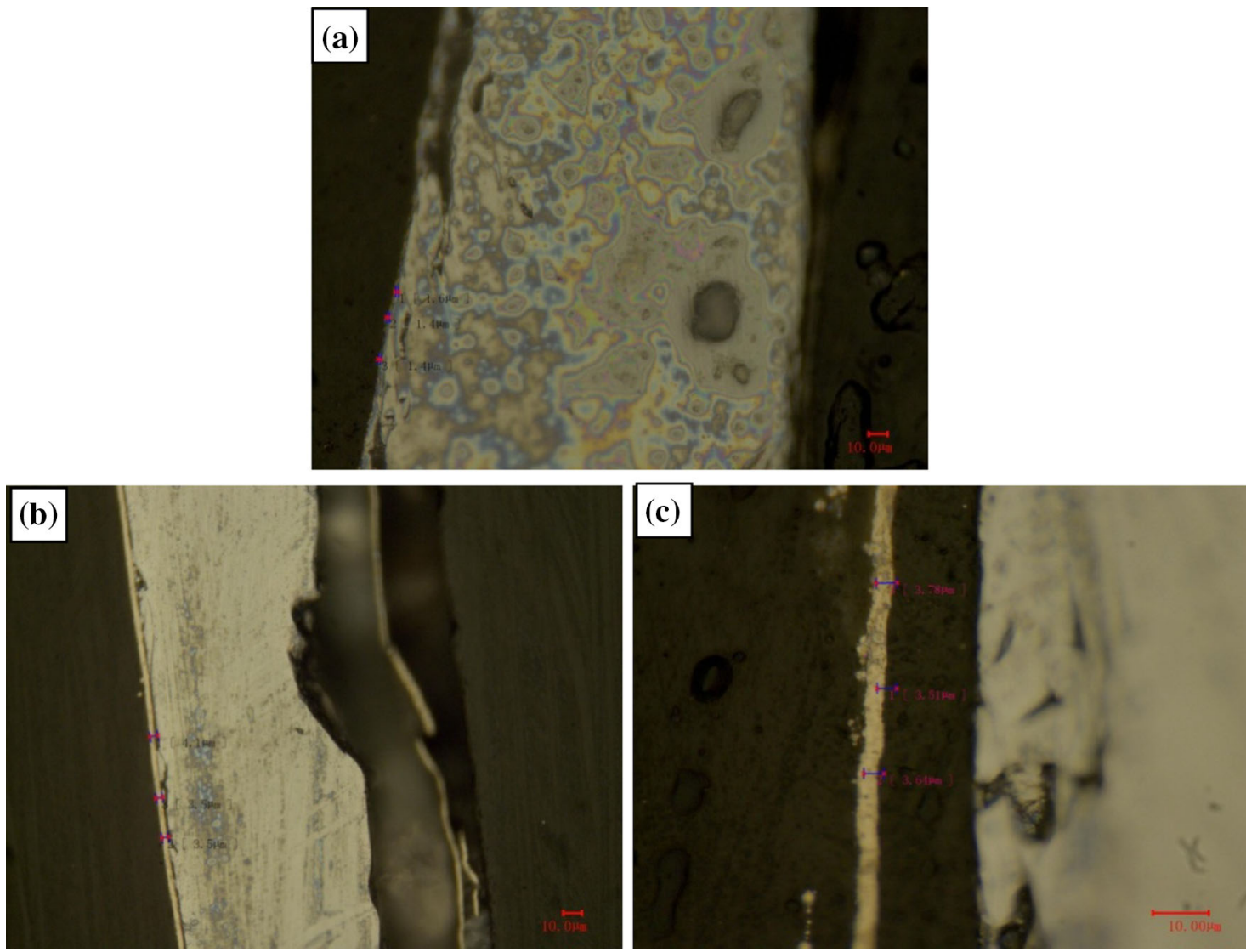

Fig. 6 Optical images of cross section of the film deposited at the different bath temperatures. Bath temperature of $60{ }^{\circ} \mathrm{C}(\mathbf{a}), 70{ }^{\circ} \mathrm{C}(\mathbf{b})$ and $80{ }^{\circ} \mathrm{C}(\mathbf{c})$

substrates, which might result from the slow nucleation rate and the release of hydrogen bubbles. Lots of bubbles were observed during deposition, which flew through the void space at the interface between film and substrate, and then built-in pressure could break the integrity of the $\mathrm{Ni}-\mathrm{P}$ film on the surface of the Si substrates (Zhang et al. 2006).

Figure 7 presents the chemical composition of the film deposited at different plating temperatures. The P-content of the deposits was not changed significantly with increasing bath temperature, and the value was kept stable at about $12 \mathrm{wt} \%$. As shown in EDS pattern, the asprepared deposit was composed only of elemental $\mathrm{Ni}$ and $\mathrm{P}$. The content of the $\mathrm{Ni}$ in the deposit was more than that of the P. It can be depicted that the films should be a high-P content alloy film. Therefore, the plating temperature had little effect on the chemical composition of the film. High- 


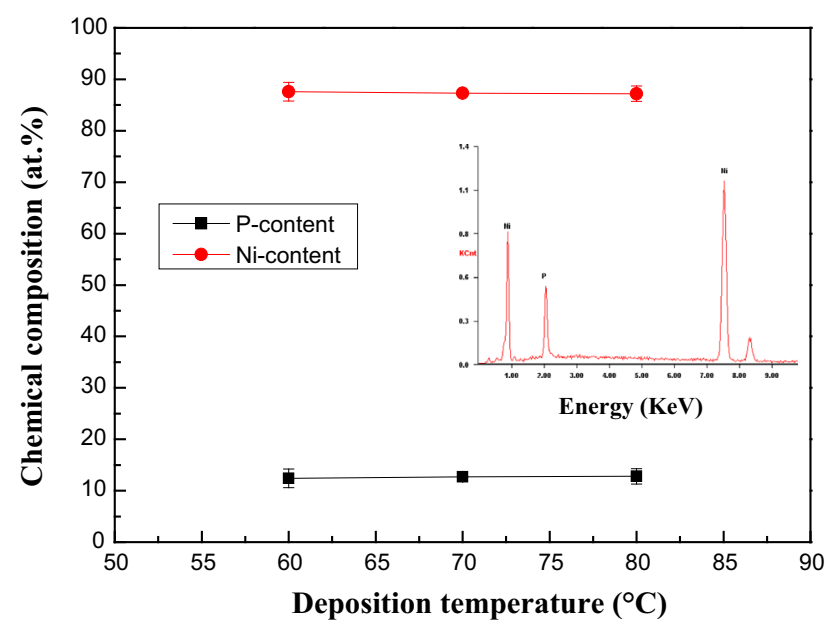

Fig. 7 Chemical composition of the film deposited at different plating temperatures

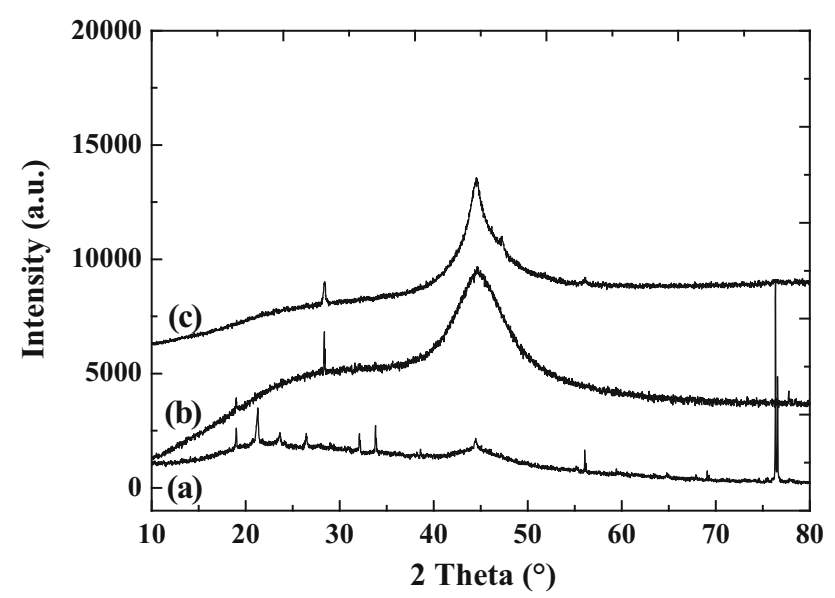

Fig. 8 XRD patterns of Ni-P films on Si substrates a $60{ }^{\circ} \mathrm{C}, \mathbf{b} 70{ }^{\circ} \mathrm{C}$ and $\mathbf{c} 80^{\circ} \mathrm{C}$

$\mathrm{P}$ deposits have amorphous structure and excellent performances in wear and corrosion resistances (Gil et al. 2008; Keong et al. 2002; Afroukhteh et al. 2012).

The effect of plating temperature on the crystallographic structure of the deposits is shown in Fig. 8. In Fig. 8a, the deposition temperature was $60{ }^{\circ} \mathrm{C}$, a board diffraction peak at $\sim 45^{\circ}$ indicates an amorphous phase formation. The diffraction peaks for polycrystalline $\mathrm{Si}$ substrate were also observed. Therefore, the thickness of Ni-P film was thin. With increasing deposition temperature, the structure of the film observed was still amorphous (Fig. $8 \mathrm{~b}$ and c). The diffraction peak of polycrystalline Si substrate almost disappeared due to the increase in film thickness. The crystallographic structure of amorphous Ni-P alloy film is in agreement with the result of high-P deposits.

\section{Discussions}

The deposition of electroless Ni-P film is a complex autocatalytic process. $\mathrm{H}_{2} \mathrm{PO}_{2}^{-}$ions act as the reducing agent that participate in oxidation and reduction reactions. $\mathrm{H}_{2} \mathrm{PO}_{2}^{-}$ was absorbed on the catalytic surface and then reacted with $\mathrm{H}_{2} \mathrm{O}$ to form $\mathrm{H}_{2} \mathrm{PO}_{3}^{-}$, free electrons and hydrogen ions $\left(\mathrm{H}^{+}\right)$, according to the following reactions (1) and (2) (Hsu et al. 2009):

$\mathrm{H}_{2} \mathrm{PO}_{2}^{-}+\mathrm{H}_{2} \mathrm{O} \rightarrow \mathrm{H}_{2} \mathrm{PO}_{3}^{-}+2 e^{-}+2 H^{+}$

$\mathrm{Ni}^{2+}+2 \mathrm{e}^{-} \rightarrow \mathrm{Ni}^{0}$

According to the reaction Eqs. (1) and (2), the deposition of electroless $\mathrm{Ni}$ could be described by the following reaction (3), which could occur in either alkaline or acid environment.

$\mathrm{Ni}^{2+}+\mathrm{H}_{2} \mathrm{PO}_{2}^{-}+\mathrm{H}_{2} \mathrm{O} \rightarrow \mathrm{H}_{2} \mathrm{PO}_{3}^{-}+2 \mathrm{H}^{+}+\mathrm{Ni}^{0}$

For the alkaline solution, the main reactions for conventional deposition of electroless $\mathrm{Ni}-\mathrm{P}$ film will be expressed by the following equations according to the hydride transfer mechanism (Zhang et al. 2011):

$\mathrm{H}_{2} \mathrm{PO}_{2}^{-}+2 \mathrm{OH}^{-} \rightarrow \mathrm{H}^{-}+\mathrm{H}_{2} \mathrm{PO}_{3}^{-}+\mathrm{H}_{2} \mathrm{O}$

$\mathrm{Ni}^{2+}+2 \mathrm{H}^{-} \rightarrow \mathrm{Ni}^{0}+\mathrm{H}_{2} \uparrow$

$\mathrm{H}_{2} \mathrm{PO}_{2}^{-}+\mathrm{H}^{-} \rightarrow 2 \mathrm{OH}^{-}+\mathrm{P}+1 / 2 \mathrm{H}_{2} \uparrow$

$\mathrm{H}_{2} \mathrm{O}+\mathrm{H}^{-} \rightarrow \mathrm{OH}^{-}+\mathrm{H}_{2} \uparrow$

According to the Eqs. (4)-(7), the hydride transfer mechanism explains the occurrence of hydrogen evolution in a bath solution containing $\mathrm{H}_{2} \mathrm{PO}_{2}^{-}$. Abdel Hamid et al. (Abdel Hamid 2003) pointed out that the increase in $\mathrm{pH}$ value for the alkaline solution resulted in the decrease of the deposition rate due to the consumption of $\mathrm{OH}^{-}$ions according to the following Eq. (8):

$\mathrm{H}_{2} \mathrm{PO}_{2}^{-}+\mathrm{OH}^{-} \rightarrow \mathrm{H}_{\text {ads }}+\mathrm{H}_{2} \mathrm{PO}_{3}^{-}+\mathrm{e}^{-}$

The combination of two $\mathrm{H}$ atoms will result in the hydrogen evolution (Eq. 9) and reduction of $\mathrm{Ni}^{2+}$ ions (Eq. 10)

$2 \mathrm{H}_{\mathrm{ads}} \rightarrow \mathrm{H}_{2} \uparrow$

$2 \mathrm{H}_{\text {ads }}+\mathrm{Ni}^{2+} \rightarrow \mathrm{Ni}^{0}+2 \mathrm{H}^{+}$

The reduced Ni mainly resulted from the reaction among the $\mathrm{Ni}$ ions and the reductant radicals (Abrantes and Correia 1994; Iwasa et al. 1968). However, the Si substrate could be oxidized in aqueous alkaline solution as following reaction Eq. (11):

$\mathrm{Si}+2 \mathrm{OH}^{-} \rightarrow \mathrm{SiO}_{2}+\mathrm{H}_{2}+2 \mathrm{e}^{-}$

On the other hand, as the Si substrate was immersed in 
the aqueous alkaline solution, the galvanic displacement reaction occurred, which is a spontaneous reaction. The spontaneous reaction for $\mathrm{Ni}$ deposition can be expressed as following Eq. (12) (Hsu et al. 2009):

$2 \mathrm{Ni}^{2+}+\mathrm{Si} \rightarrow 2 \mathrm{Ni}^{0}+\mathrm{Si}^{4+}$

During this spontaneous reaction, the $\mathrm{Si}$ substrate surface was oxidized and became a catalytic surface inducing further co-deposition of Ni-P film. Therefore, the oxidation and reduction reactions of $\mathrm{H}_{2} \mathrm{PO}_{2}{ }^{-}$ions began to occur, followed by co-deposition of Ni-P film. In this work, Si substrate was not done by sensitizing and activation processes, the Ni nucleation on the surface of $\mathrm{Si}$ substrate was limited due to self-activation. The evidence could be observed under dense layer with a sparse particle distribution (Fig. 3b). The EDS pattern in Fig. 4 also proved that the Ni nucleation was $\mathrm{Ni}$ nuclei particles were formed preferentially in initial nucleation stage. The above discussion has been ascertained by further experiments, as shown in Fig. 9. Figure 9 shows the SEM micrographs and chemical composition distribution of fracture surface of the film. The P-content in the deposit was approximately $24 \pm 0.2 \mathrm{wt} \%$. The thickness of the film was uniform and dense. However, the interface between the film and the substrate was not homogeneous due to the effect of the substrate surface. There are many big particles like some nodules infiltrated into Si substrate. The EDS line profile showed that $\mathrm{Ni}$ concentration has a sharp peak with a sudden increase at the interface between the deposit and the substrate, which is assertive evidence to prove that $\mathrm{Ni}$ nuclei particles were formed preferentially in initial nucleation stage.

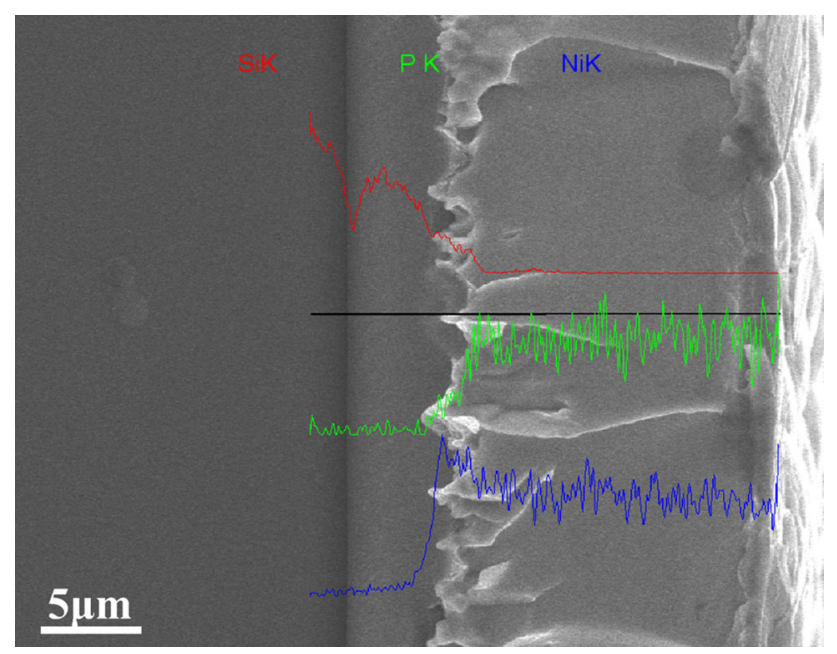

Fig. 9 SEM micrograph and line scanning analysis of the EDS of the fracture surface of the film (bath chemistry: $25 \mathrm{~g} \mathrm{~L}^{-1} \mathrm{Ni}^{2+}, 40 \mathrm{~g} \mathrm{~L}^{-1}$ $\mathrm{H}_{2} \mathrm{PO}_{2}^{-}, 20 \mathrm{~g} \mathrm{~L}^{-1} \mathrm{Cit}^{-}$; Deposition conditions: $\mathrm{pH}$ of 10.0 , bath temperature of $70{ }^{\circ} \mathrm{C}$, no additive was used)
The reducing agent was added and the nucleated $\mathrm{Ni}$ particles were produced, and then $\mathrm{Ni}-\mathrm{P}$ film was grown rapidly. Coincidentally with $\mathrm{Ni}$ reduction, $\mathrm{H}_{2} \mathrm{PO}_{2}^{-}$ions are reduced to elemental $\mathrm{P}$ and oxidized to $\mathrm{H}_{2} \mathrm{PO}_{3}^{-}$as the following reaction (13):

$2 \mathrm{H}_{2} \mathrm{PO}_{2}^{-} \rightarrow \mathrm{H}_{2} \mathrm{PO}_{3}^{-}+\mathrm{P}+\mathrm{OH}^{-}+1 / 2 \mathrm{H}_{2}$

Island growth was evident and remarkable sparse sphere particle nucleation was present. Then, islands grew and then met one another and drove to form a continuous film. Adhesion of the Ni-P film with $\mathrm{Si}$ substrate is naturally poor because of the sparsely distributed $\mathrm{Ni}$ nuclei particles in initial nucleation stage (see Fig. 3b, Fig. 4b and Fig. 9). Nuclei are firstly bonded to the substrate surface. In initial nucleation stage, nucleation rate of $\mathrm{Ni}$ were insufficient, which could cause a weak adhesion between the Ni-P layer and Si substrate (Wei et al. 2015). Lack of attachment areas and sites on the Si wafer caused the Ni-P layer to peel off easily.

\section{Conclusions}

Ni-P film was electrolessly deposited on the surface of p-type polycrystalline $\mathrm{Si}$ in an alkaline bath solution at $60-80{ }^{\circ} \mathrm{C}$ and $\mathrm{pH}$ value of 10.0 . The conclusions were made as following:

(1) Ni-P films were composed of an amorphous phase, no regardless of plating temperature. The stable value P-content of the film was maintained at about $12 \mathrm{wt} \%$ with increasing bath temperature. The deposition rate of the film was increased with increasing bath temperature.

(2) The surface of the film was dense and no cracking was found at the plating temperatures of 60 and $80{ }^{\circ} \mathrm{C}$. However, the Ni-P film electrolessly deposited at 70 and $80{ }^{\circ} \mathrm{C}$ had a poor adherence to $\mathrm{Si}$ substrate with evidence of delamination because of the slow nucleation rate in the initial nucleation stage.

(3) The nano-sized globular particles were formed at initial nucleation stage. The nuclear layer was composed of a sparse particle distribution. Some regions were not completely deposited by the nuclear particles, which could be influenced by the effect of the competitive between the initial nucleation stage and layer growth stage.

(4) A mechanism of the proposed electroless Ni-P deposits on $\mathrm{Si}$ substrates is the nucleation reactions and film growth. In the initial nucleation stage, nucleation reactions could occur in the neighborhood of the original Ni nodules to form an irregular nodular structure. 
Acknowledgements This work has been supported by the Natural Science Foundation for Colleges and Universities in Jiangsu Province and Jiangsu Province Science Foundation for Youths (Grant Number: BK20150260).

Open Access This article is distributed under the terms of the Creative Commons Attribution 4.0 International License (http:// creativecommons.org/licenses/by/4.0/), which permits unrestricted use, distribution, and reproduction in any medium, provided you give appropriate credit to the original author(s) and the source, provide a link to the Creative Commons license, and indicate if changes were made.

\section{References}

Abdel Hamid Z (2003) Mechanism of electroless deposition of Ni-W$\mathrm{P}$ alloys by adding surfactants. Surf Interface Anal 35:496-501

Abrantes LM, Correia JP (1994) On the mechanism of electroless NiP plating. J Electrochem Soc 141:356-2360

Afroukhteh S, Dehghanian C, Emamy M (2012) Preparation of electroless Ni-P composite coatings containing nano-scattered alumina in presence of polymeric surfactant. Progress Nat Sci Mater Inter 22:318-325

Andersson HA, Thungstrom G, Nilsson H-E (2008) Electroless deposition and silicidation of $\mathrm{Ni}$ contacts into p-type porous silicon. J Porous Mater 15:335-341

Ashassi-Sorkhabi H, Rafizadeh SH (2004) Effect of coating time and heat treatment on structures and corrosion characteristics of electroless Ni-P alloy deposits. Surf Coat Technol 176:318-326

Bulasara VK, Thakuria H, Uppaluri R et al (2011) Combinatorial performance characteristics of agitated nickel hypophosphite electroless plating baths. J Mater Process Technol 211:1488-1499

Chen Y-C, Sermon Wu Y-C, Chao C-W et al (2001) Electroless plating $\mathrm{Ni}$ induced crystallization of amorphous silicon thin films. Jap J Appl Phys 41:6356-6357

Cheong WJ, Luan BL, Shoesmith DW (2007) Protective coating on $\mathrm{Mg}$ AZ91D alloy - the effect of electroless nickel (EN) bath stabilizers on corrosion behaviour of Ni-P deposit. Corros Sci 49:1777-1798

Furukawa S, Mehregany M (1996) Electroless plating of nickel on silicon for fabrication of high-aspect-ratio microstructures. Sensors Actuators A 56:261-266

Gil L, Jiménez L, Castro AC et al (2008) Evaluation of the effect of Ni-P coating on the corrosion resistance of the aluminium 7075 T6 alloy. Rev Metal Madrid 44:66-73

Hsu HF, Tsai CL, Lee CW et al (2009) Mechanism of immersion deposition of $\mathrm{Ni}-\mathrm{P}$ films on $\mathrm{Si}(100)$ in an aqueous alkaline solution containing sodium hypophosphite. Thin Solid Films 517:4786-4791

Hua BN, Sun RX, Yu G et al (2013) Effect of bath pH and stabilizer on electroless nickel plating of magnesium alloys. Surf Coat Technol 228:84-91
Hung A (1985) Effects of thiourea guanidine hydrochloride on electroless copper plating. J Electrochem Soc 132:1047-1049

Iwasa H, Yokozawa M, Teramoto I (1968) Electroless nickel plating on silicon. J Electrochem Soc 115:485-488

Keong K, Sha W, Malinov S (2002) Crystallisation kinetics and phase transformation behaviour of electroless nickel-phosphorus deposits with high phosphorus content. J Alloys Compounds 334:192-199

Liu WL, Hsieh SH, Tsai TK et al (2006) Temperature and $\mathrm{pH}$ dependence of the electroless $\mathrm{Ni}-\mathrm{P}$ deposition on silicon. Thin Solid Films 510:102-106

Liu Jiana, Si Fujian, Li Dond et al (2015) Effect of bath pH on electroless Ni-P coating deposited on open-cell aluminum foams. Surf Rev Lett 22:1550076-1-1550076-12

Lobanova LL, Batalova EV, Khranilov YP (2011) Reagent techniques for nickel recovery from spent electroless nickel-plating solutions. Russian J Appl Chem 81:202-206

Moniruzzaman M, Roy S (2011) Effect of pH on electroless Ni-P coating of conductive and nonconductive materials. Inter $\mathrm{J}$ Automot Mechan Eng 4:481-489

Osifuye CO, Popoola API, Loto CA et al (2014) Effect of bath parameters on electroless Ni-P and Zn-P deposition on 1045 steel substrate. Int J Electrochem Sci 9:6074-6087

Rahman A, Jayaganthan R (2015) Effect of pH values on nanostructured Ni-P films. Applied Nanoscience 5:493-498

Shacham-Diamand Y, Osaka T, Okinaka Y et al (2015) 30 years of electroless plating for semiconductor and polymer microsystems. Microelectron Eng 132:35-44

Singh AK, Bajpai VK, Solanki CS (2014) Effect of light on electroless nickel deposition for solar cell applications. Energy Procedia 54:763-770

Sudagar J, Lian JS, Sha W (2013) Electroless nickel alloy composite and nano coatings-a critical review. J Alloy Comp 571:183-204

Wei T-C, Pan T-C, Chen C-M et al (2015) Annealing-free adhesive electroless deposition of a nickel/phosphorous layer on a silanecompound-modified Si wafer. Electrochem Commun 54:6-9

Wu WP, Eliaza N, Gileadi E (2015) The Effects of $\mathrm{pH}$ and temperature on electrodeposition of Re-Ir-Ni coatings from aqueous solutions. J Electrochem Soc 162:D20-D26

Xie HW, Zhang BW (2002) Effects of preparation technology on the structure and amorphous forming region for electroless $\mathrm{Ni}-\mathrm{P}$ alloys. J Mater Process Technol 124:8-13

Yoo J, Yu G, Yi J (2011) Large-area multicrystalline silicon solar cell fabrication using reactive ion etching (RIE). Solar Energy Mater Solar Cells 95:2-6

Zhang X, Ren F, Goorsky MS et al (2006) Study of the initial stage of electroless $\mathrm{Ni}$ deposition on $\mathrm{Si}$ (100) substrates in aqueous alkaline solution. Surf Coat Technol 201:2724-2732

Zhang YC, Runan H, Rong X (2011) Electroplating Handbook. National Defence Industry Press pp:532-550 (In Chinese)

Zhou XW, Jin HM, Zhang LN (2009) Influence of pH value on microstructure and thermal stability of $\mathrm{Ni}-\mathrm{P}$ electroless coating prepared in acidic condition. Chin Che Lett 20:845-848 